\title{
PREPARATION OF INACTIVATED INFECTIOUS BURSAL DISEASE VIRUS VACCINE FROM CLASSICAL STRAIN AND LOCAL VARIANT ISOLATES
}

\author{
Nada A. Fathy and Abd El-Moneam M. M.
}

Veterinary Serum and Vaccine Research Institute, Abassia, Cairo, Egypt. Corresponding author: Abd El-Moneam M. M., email: dr_mahmoud_vsvri@yahoo.com

\begin{abstract}
This study was conducted to assess an inactivated vaccine prepared from local field isolates of Infectious Bursal Disease (IBD) "local variant and virulent isolates" and a classical strain "bursa vacc" to improve the full control over the problem of IBD in Egypt. This experiment applied on 21 day old SPF chicks divided into six groups, the first group was vaccinated with inactivated vaccine containing (local variant isolate, classical bursa vacc strain and virulent isolate), the second group was vaccinated with inactivated vaccine containing (classical bursa vacc strain and local variant isolate), the third group was vaccinated with classical bursa vacc vaccine, and the group 4 vaccinated with local variant isolate vaccine while last two groups were left as a positive and negative control groups. The immune response of chicks was evaluated in vitro by measuring serum neutralization test (SNT) and enzyme linked immunosorbent assay (ELISA) and in vivo by challenging birds with $10^{3.5} \mathrm{EID}_{50}$ / dose of virulent virus of infectious bursal disease virus (vvIBDV). The highest average antibody level was obtained at the $4^{\text {th }}$ week post vaccination in chicks in group 1 vaccinated with (local variant isolate, classical bursa vacc and local virulent isolate) vaccine, while the chicks in group 3 vaccinated with bursa vacc vaccine showed the lowest antibody level at the same week post vaccination using SNT and ELISA. The challenge of group 1, 2, 3 and 4 showed protection of $97.5 \%, 90 \%, 75 \%$ and $90 \%$ respectively using very virulent IBDV 28 day post vaccination with no clinical signs or lesions on examination. It was concluded that we can use an inactivated vaccine prepared from (classical strain "bursa vacc" and local variant and virulent isolates) of Infectious Bursal Disease (IBD) virus as a method for control IBD disease in Egypt.
\end{abstract}

Original Article:

DOI:https://dx.doi.org/10.21608/jav $\underline{\text { s.2018.62726 }}$

Received: 09 june, 2018.

Accepted: 26 June, 2018.

Published: 12 July, 2018.

Keywords: classical bursa , ELISA, inactivated vaccine, IBD, SNT.

\section{INTRODUCTION}

Gumboro disease of chicken was first observed by (Cosgrove, 1962) in Gumboro district of Delaware, USA, hence the name "Gumboro disease. Other names of the disease entity based on the lesions produced included avian nephrosis- nephritis, avian infectious bursitis and Infectious bursal disease. Infectious bursal disease virus (IBDV) is the causative agent of infectious bursal disease (IBD), a highly contagious immunosuppressive disease in young chicken. Infectious bursal disease virus (IBDV) is a nonenveloped virus; it consists of the bi-segmented double-strand RNA genome and the genome-enclosing viral capsid that is mainly formed by the viral protein VP2 (Coulibaly et al., 2005) which targets immature B lymphocytes of the bursa of Fabricius (BF), a primary lymphoid organ in avian species, and subsequently causes B-cell depletion in bursal follicles.
Macrophages may be susceptible to IBDV reviewed by (Khatri and Sharma, 2007). Differences in susceptibility may also occur between different SPF chicken lines. The highest susceptibility to acute IBD occurs in chicken between 3 and 6 weeks of age (Eterradossi and Saif, 2013).

Two serotypes of infectious bursal disease virus (IBDV) are known to exist. Serotype 1 viruses replicate in the bursa of Fabricius and some serotype 1 viruses cause clinical disease in chicken. Antibodies or virus are sometimes found in other avian species, but no signs of infection are seen. Serotype 2 viruses have been detected from the respiratory tract of turkeys, cloacal swabs of ducks or in the bursa of Fabricius of chicken. Antibodies against serotype 2 viruses are very widespread in turkeys and are sometimes found in chicken and ducks. There is no report of clinical disease caused by infection with serotype 2 virus (Eterradossi and Saif, 2013). Pathogenic serotype 1 
(IBDV) is a pathogenic strains in chicken that classified as classical virulent (cvIBDV), very virulent (vvIBDV) and antigenic variant (avIBDV). (Van den Berg et al., 2004).

Outbreaks of IBD emerged among broilers and layers in Middle East, Africa and South America causing mortality (Muller et al., 2003). IBD has been a serious problem in Egypt, vvIBDV strains were reported since its first introduction in 1989 (ElBatrawi, 1990), while variant viruses was first described as newly emergent in USA with increased mortality even in vaccinated flocks (Snyder $\boldsymbol{e t}$ al., 1988). These variant strains differed from classical ones in which they caused a rapid bursal atrophy with minimal inflammatory response. Circulating IBDV isolates was isolated from flocks vaccinated with classical IBDV vaccines (Abdel-Alim et al., 2003; Hussein et al., 2003, Metwally et al., 2003; Metwally et al., 2009; Helal et al., 2012; Mohamed et al., 2014; Sara et al., 2014; and Nada, 2015).

The terms "variant", "classical" and "very virulent" have been used to describe IBDV strains that exhibit differences in pathogenicity. Based on the signs and lesions observed in two lines of White Leghorn SPF chicken during experimental IBD virus infection following a $10^{5} 50 \%$ embryo infective dose $\left(\mathrm{EID}_{50}\right)$ challenge, North American "variant" IBDVs induce little clinical signs and no mortality but marked bursal lesions, "classical" IBDVs induce approximately 10$50 \%$ mortality with typical signs and lesions whereas "very virulent" IBDVs induce approximately 50-100\% mortality with typical signs and lesions (Eterradossi et al., 1999 personal observation).

Important methods of IBD prevention and control in the poultry industry are disinfection, biosecurity and vaccination at the appropriate time (Chansiripornchai and Sasipreeyajan, 2009). Generally, IBD is effectively controlled by vaccination worldwide (Muller et al., 2003). Different types of vaccines are mostly available for the controlling of IBD include Live attenuated vaccine (egg adapted or tissue culture one), inactivated oil-emulsion adjuvant vaccine and recombinant IBDV-vp2 protein vaccine (Schijns et al., 2008). Inactivated oil adjuvanted vaccine used to boost and prolong immunity against IBD and these vaccines are most effective in chicken that have been primed with live virus either in the form of a vaccine or field exposure to the virus (lukert and saif, 2003). In the United States of America, Australia and other countries, variant types of IBDV that induce severe atrophy of the bursa, but against which the classical type of IBD vaccine does not protect (Sapats and Ignjatovic, 2000), so that in this study we try to prepare an inactivated vaccine protect chicken against variant, virulent isolates and classical strain of IBD .
This study aims to prepare and evaluate an inactivated IBD vaccine prepared from a local field isolates and classical strain (bursa vacc) of IBDV propagated on SPF-ECE as a method of control and decrease the economic losses in chicken industry due to IBD.

\section{MATERIALS AND METHODS}

\section{Viral strains}

\section{Local variant isolate of Infectious Bursal} Disease Virus (IBDV)

Local Variant isolate was in form of infectious allantoic fluid; isolated from field broiler cases in Giza government Egypt (2013/2014) and identified by PCR and sequence analysis (Nada, 2015). This virus was propagated in SPF-ECE for several serial passages. Its infectivity titer was $10^{8.5} \mathrm{EID}_{50} / \mathrm{ml}$ and it was used in preparation of vaccine under test. The propagation of viruses and titration in SPF-ECE were carried out as described by (Villegas, 1990) and $\mathrm{EID}_{50}$ is calculated according to method (Reed and Muench, 1938).

\section{Very virulent isolate of IBD (vvIBD) virus}

Virulent virus of IBD of field isolate was obtained from Central Lab for Evaluation of Veterinary Biologics (CLEVB). Its infectivity titer of $10^{8.6} \mathrm{EID}_{50} /$ $\mathrm{ml}$ was used for preparation of vaccine under test and of $10^{3.5} \mathrm{EID}_{50}$ /dose was used for challenge of all experimental vaccinated chicks 28 day post vaccination.

\section{A classical (Bursa vacc) strain}

The virus was supplied by the Department of Newcastle vaccine research belongs to Veterinary Serum and Vaccine Research Institute, Abbasia, Cairo. The virus has an infectivity titer of $10^{6.8}$ EID50/ $\mathrm{ml}$ and used for preparation of the inactivated IBDV vaccine under test.

\section{Specific Anti- IBD serum for different strains}

It was kindly supplied by the Department of Newcastle disease vaccine research belongs to Veterinary Serum and Vaccine Research Institute, Abbassia, Cairo which prepared according to (Mc Ferran et al., 1980) used as positive control in SNT.

\section{Primary chicken embryo fibroblast (CEF) cell culture}

Primary CEF cell culture was obtained from Central Lab for Evaluation of Veterinary Biologics (CLEVB). It was prepared according to (Villegas, 1990) and used for propagation, adaptation and titration of all IBDV strains and in serum neutralization test.

\section{Enzyme linked immuno-sorbent assay (ELISA)}

ELISA Kit was obtained from Symbiotic Corporation 11011 VIA Forntera San Digo; Infactious bursal kit with Batch no FS5155 and used according to (Snyder et al., 1986). 


\section{Serum neutralization test (SNT)}

Quantitative SNT was carried out on sera of vaccinated chicks for titration of IBD neutralizing antibodies against $100 \mathrm{TCID} 50 / \mathrm{ml}$ of the IBDV adapted on CEF cells using the micro titer technique according to (Florence et al., 1992).

\section{Preparation of the inactivated IBDV vaccine Propagation of IBDV in SPF-ECE}

The locally isolated IBDV isolates and bursa vacc strain used for vaccine preparation were propagated via chorioallantoic membrane (CAM) in 911 days old SPF-ECE $(0.2 \mathrm{ml} / \mathrm{egg})$ according to (Allan et al., 1973). Harvested CAMs were homogenized and the virus was titrated on 9-11 day old SPF-ECE according to (Cho and Edgar, 1969) and the titer of the virus were calculated according to (Reed and Meunch, 1938). The aqueous phase used for vaccine formulation had a titer $10^{8.5} \mathrm{EID}_{50} / \mathrm{ml}$ for local variant isolate and had a titer $10^{8.6} \mathrm{EID}_{50} / \mathrm{ml}$ for local virulent isolate and had a titer $10^{6.8} \mathrm{EID}_{50} / \mathrm{ml}$ of the bursa vacc seed. The positive signs of inoculated eggs with IBDV were edema and hemorrhage of CAM and embryo with liver necrosis and death.

\section{Completion of Inactivation of the propagated antigen}

Inactivation of the viruses was done using formalin $(37 \%)$ Analar, $\mathrm{BDH}$ that was used in a dilution 1:1000 according to (Beard, 1989). Completion of the virus inactivation was tested by passage in 9-11 day old SPF embryonated eggs $(0.1 \mathrm{ml}$ /egg) via CAM and examined daily for 5 days. It was noticed that, there were no any pathological lesions and / or deaths of inoculated embryos, compared with that of the control one.

\section{Formulation of the vaccine}

Four vaccines were prepared as water in oil emulsion (W/O) using Montanide ISA71 at a ratio of $3 / 7$ (v/v) aqueous /oil ratio. Manufacturing process was carried out according to the standard protocol of SEPPIC and manufacture instruction as following:

Vaccine (1): inactivated IBD vaccine (local variant isolate, virulent isolate and classical bursa vacc strain). This vaccine has a final titer $10^{8.5} \mathrm{EID}_{50} / \mathrm{ml}$.

Vaccine (2): inactivated IBD vaccine (local variant isolate and classical bursa vacc strain). This vaccine has a final titer $10^{8.0} \mathrm{EID}_{50} / \mathrm{ml}$.

Vaccine (3): inactivated IBD vaccine (classical bursa vacc vaccine). This vaccine has a final titer $10^{6.8}$ $\mathrm{EID}_{50} / \mathrm{ml}$.

Vaccine (4): inactivated IBD vaccine (local variant isolate). This vaccine has a final titer $10^{8.5} \mathrm{EID}_{50} / \mathrm{ml}$.

\section{Experimental design}

Three hundred of 21 day old SPF chicks were obtained from SPF poultry project, Kom Oshim, ELFayoum Governorate. This farm is a part from Ministry of Agriculture in Egypt. All birds were housed in a separated negative pressure filtered air isolators provided with autoclaved commercial water and feed. These chicks used to study the efficacy of prepared vaccines. Chicks were divided into 6 groups (50 chicks /each group) as following: Forty chick for each group where they were vaccinated with vaccine $1,2,3$ and 4 respectively using a dose of $0.5 \mathrm{ml} /$ bird inoculated S/C while Group 5 left as unvaccinated challenged chicks (+ve control) and Group 6 left as unvaccinated unchallenged chicks (-ve control).

Ten chicks from each group have kept for safety test by inoculation douple dose for each vaccine.Serum samples were collected from all chicks (vaccinated and non- vaccinated) weekly till 4th week post vaccination and before challenge. The sera were inactivated at $56^{\circ} \mathrm{C}$ for 30 minutes, and then stored at $20^{\circ} \mathrm{C}$ until used in ELISA and SNT.

\section{Evaluation of the prepared inactivated IBDV oil emulsion vaccines}

Testing the quality control of the prepared inactivated IBDV vaccines including sterility and safety was carried out according to (Code of American Federal Regulation, USA 2017).

\section{RESULTS AND DISCUSSION}

Two parameters were used for the evaluation the efficacy of different IBD prepared vaccines including antibody level monitoring by ELISA and SNT and the most important parameter which is protection percent $(\%)$ by challenge using virulent strain of IBDV. The propagation of the bursal homogenate of the isolated IBDV was carried out for five serial passages on SPF-ECE through chorioallantioc membrane. There was an increase in infectivity titer $\mathrm{EID}_{50}$ from the first to the fifth passage. This result agreed with that obtained by (Nadia, 2011). Inactivation of the seed egg adapted IBDV using $0.1 \%$ formalin solution, showed complete virus inactivation after $24 \mathrm{hrs}$. The completion of virus inactivation was tested by its inoculation in 9-11 days old SPF-ECEs on CAM that showed no pathological lesions and / or deaths of inoculated embryos, compared with the control one. This result agreed with the studies used formalin $0.1 \%$ for IBDV inactivation showing complete virus inactivation after 24 hrs by (Habib et al., 2006).

\section{Sterility and safety test}

Testing quality of the prepared inactivated IBDV vaccines, as Sterility test was applied to confirm that the prepared vaccines were free from bacterial, mycoplasma and fungal contamination by inoculation into nutrient agar, thioglycolate broth, PPLO that were incubated at $37^{\circ} \mathrm{C}$ for 72 
hours and Saburaoud glucose agar that was incubated at $25^{\circ} \mathrm{C}$ for 14 days showed that all prepared experimental vaccines were free from any bacterial and fungal contaminants. Safety of The prepared inactivated IBDV vaccines was tested in 60 chicks of 3 weeks old chicks (40 chicks inoculated with "double dose" of prepared vaccines under test subcutaneous at the neck and 20 chicks kept as a control +ve and control -ve). After 5 days of inoculation, some birds were subjected to post mortem examinations to detect any pathological lesions. It was observed that, there were no local or systemic reactions and also, no mortality in inoculated chicks till the end of observation period. These result in agreement with the directions of (Code of Federal Regulations USA, 2017).

\section{Potency of the prepared vaccine}

Humoral immunity plays an important role in poultry against IBDV infection. Current available live and inactivated IBD vaccines are usually evaluated based on their capacity of inducing antibody response, which contributes to the protection elicited by the vaccine (Tsukamoto et al., 1995; and Rautenschlein et al., 2002). The ELISA and SNT procedure are usually accepted as a serological test for antibody level to IBDV in poultry flocks (Briggs et al., 1986).

As serum neutralization test (SNT), the results in table (1) revealed that the mean $\log _{2}$ serum neutralizing antibody titer of chicks vaccinated with local field isolates (virulent and variant isolates) and classical bursa vacc strain in group 1 started to increase from the first week post vaccination $\left(8 \quad \log _{2}\right)$, reached the suitable high level at 3rd week post vaccination (128 $\left.\log _{2}\right)$, reached the highest level at $4^{\text {th }}$ week post vaccination $\left(256 \log _{2}\right)$. Group 2 vaccinated with inactivated IBDV vaccine consist of a classical bursa vacc strain and a local variant isolate showed increased mean $\log _{2}$ serum neutralizing antibody titer started from the first week post vaccination $\left(8 \log _{2}\right)$, reached the suitable high level at $3^{\text {rd }}$ week post vaccination $\left(64 \log _{2}\right)$, reached high level at 4 th week post vaccination $\left(128 \log _{2}\right)$.

The group 3 vaccinated with the prepared inactivated classical IBDV vaccine started to slightly increased from the first week post vaccination $\left(4 \log _{2}\right)$, reached the high level at 2 nd week post vaccination $\left(8 \log _{2}\right)$, then returned to the low level at $3^{\text {rd }}$ and $4^{\text {th }}$ weeks post vaccination (4 $\log _{2}$ ) these results agreed with (Susan et al., 2013) who reported that chicken vaccinated with intermediate and intermediate plus strains gave the lowest SNT antibody mean titer. Also agreed with (Magda et al., 2013) who clarified that the experimental birds vaccinated with two doses of IBD vaccine (Intermediate and Intermediate plus strains) produce higher immune response than that received one dose of Intermediate vaccine "classical strain".

The group Four vaccinated with inactivated local variant IBDV vaccine showed increased mean $\log 2$ serum neutralizing antibody titer started from the first week post vaccination $\left(8 \log _{2}\right)$, reached the suitable high level at $2^{\text {nd }}$ and $3^{\text {rd }}$ week post vaccination $\left(64 \log _{2}\right)$, then recording the highest level at $4^{\text {th }}$ week post vaccination $(128$ $\log _{2}$ ). These results agreed with (Amal, 2001) who reported that the variant isolate vaccine prepared from ISA-70 oil adjuvant induced the highest antibody titer after 4 weeks post vaccination and remained high up to 12 weeks post vaccination.

Table 1: Mean IBD serum neutralizing antibody titers in vaccinated chicks with the four prepared inactivated IBDV vaccines.

\begin{tabular}{|c|c|c|c|c|}
\hline $\begin{array}{c}\text { Weeks post } \\
\text { vaccination }\end{array}$ & \multicolumn{4}{|c|}{$\begin{array}{c}\text { Mean } \log _{2} \text { serum neutralizing } \\
\text { antibody titers }\end{array}$} \\
\hline & Gp 1 & Gp 2 & Gp 3 & Gp 4 \\
\cline { 2 - 5 } 1 & 8 & 8 & 4 & 8 \\
\hline 2 & 32 & 16 & 8 & 64 \\
\hline 3 & 128 & 64 & 4 & 64 \\
\hline 4 & 256 & 128 & 4 & 128 \\
\hline
\end{tabular}

Group 1: vaccinated with inactivated IBD vaccine consisted of (variant isolate+virulent isolate+bursa vacc)

Group2: vaccinated with inactivated IBD vaccine consisted of (variant isolate +bursa vacc)

Group 3: vaccinated with inactivated IBD vaccine (bursa vacc strain) Group 4: vaccinated with inactivated IBD vaccine (variant isolate) **group (5): unvaccinated challenged (+ve) control group did show 2 $\log _{2}$ antibody response against IBDV.

** group (6): unvaccinated unchallenged (-ve) control group did show 2 $\log _{2}$ antibody response against IBDV

Table (2) shown, The mean ELISA serum antibody titers of chicks in group 1 vaccinated with local field isolates (virulent and variant isolates) and classical bursa vacc strain showed increase the antibody level from $1^{\text {st }}$ week post vaccination (568), reached the highest level at $4^{\text {th }}$ week post vaccination (2814). These results agreed with (Silke et al., 2003) who reported that virulent 
strain of IBDV induced the highest enzyme-linked immunosorbent assay (ELISA) antibody levels detected at days 8-29 Post inoculation and the best protection against challenge virus replication in comparison with mild and intermediate strain of classical IBDV.

Table 2: Mean IBD ELISA serum antibody titers in vaccinated chicks with the four prepared inactivated IBDV vaccines.

\begin{tabular}{|c|c|c|c|c|}
\hline $\begin{array}{c}\text { Weeks post } \\
\text { vaccination }\end{array}$ & \multicolumn{4}{|c|}{$\begin{array}{c}\text { Mean ELISA serum antibody } \\
\text { titers }\end{array}$} \\
\hline & Gp 1 & Gp 2 & Gp 3 & Gp 4 \\
\cline { 2 - 5 } 1 & 568 & 324 & 216 & 584 \\
\hline 2 & 616 & 459 & 459 & 855 \\
\hline 3 & 855 & 616 & 201 & 888 \\
\hline 4 & 2814 & 855 & 126 & 846 \\
\hline
\end{tabular}

Group 1: vaccinated with inactivated IBD vaccine consisted of (variant isolate+virulent isolate+bursa vacc)

Group2: vaccinated with inactivated IBD vaccine consisted of (variant isolate +bursa vace)

Group 3: vaccinated with inactivated IBD vaccine (bursa vacc strain) Group 4: vaccinated with inactivated IBD vaccine (variant isolate)

**group (5): unvaccinated challenged (+ve) control group did show 300 mean ELISA serum antibody titer against IBDV.

**group (6): unvaccinated unchallenged (-ve) control group did show 300 mean ELISA serum antibody titer against IBDV

*Positive ELISA titers are over 450 according to kind of used kits.

The humoral immune response of chicks in group 2 showed increased mean ELISA serum antibody titer started from the first week post vaccination (324), reached the high level at $4^{\text {th }}$ week post vaccination (855). While chicks in group 3 that showed low mean ELISA serum antibody titer started from the first week post vaccination (216), then slightly increased at $2^{\text {nd }}$ week post vaccination as (459) and reached the lowest level at $3^{\text {rd }}$ and $4^{\text {th }}$ week post vaccination as (201) and (126) respectively. These results agreed with (Mahgoub, 2010) who mentioned that intermediate and intermediate plus strains are sometimes administered at 1 day old to protect any chicken in the flocks that may have no or minimum levels of maternal derived antibodies and (Magda et al., 2013) who clarified that the experimental birds vaccinated with two doses of IBD vaccine (Intermediate and Intermediate plus strains) exhibited higher immune response than that received one dose of Intermediate vaccine classical strain.
Chicks in Group 4 showed increased mean ELISA serum antibody titer started from the first week post vaccination (584), and reached at $4^{\text {th }}$ week post vaccination to level (846). The previous results were compared with that of the control group of chicks that had negative results (ELISA serum antibody titers below 450) against the virus. These results agreed with the results of (Amal, 2001) who found that evaluation of the chick's immune response to the locally prepared inactivated IBDV vaccine adjuvant with Montanide oil ISA 70 showed the highest antibody titers at $4^{\text {th }}$ week post vaccination and were found to be protective and also agreed with that of (Habib et al., 2006), who showed that on the basis of humoral immune response, the inactivated IBDV vaccines were immunogenic with increased antibody titers in all inoculated groups two weeks post inoculation. In addition, these results agreed with the facts showed that the humoral immune response plays the principal role in defense against vvIBDV (Lukert and Saif, 1997). Inoculation of inactivated IBDV could give complete protection with no obvious IBD clinical signs, as reported previously by (Maas et al., 2001).

Figure (1) and (2) showed, The chicken in group 3 that vaccinated with inactivated bursa vacc vaccine show the lowest mean $\log 2$ serum neutralizing antibody titer and mean ELISA titer level and antibody titer. These results agreed with (Thayer et al., 1983) who proved that IBDV (bursa vacc) in the monovalent form had a GMT of 55 at $1^{\text {st }}$ day post vaccination. The GMTs declined at steady and comparable rates for all treatment groups, with detectable titers manifested through 21 days of age post vaccination as a GMT of 6 . There were no detectable titers at 28 days of age.

On the other hand the chicken in group 1 that vaccinated with virulent, variant isolates and a classical strain show the highest mean $\log _{2}$ serum neutralizing antibody titer and mean ELISA titer level and these results agreed with (Silke $\boldsymbol{e t}$ al., 2003) who reported that virulent strain of IBDV induced the highest antibody levels detected and the best protection against challenge virus replication in comparison with mild and intermediate strain of classical IBDV. 
Figure 1: Mean IBD serum neutralizing antibody titers in vaccinated chicks with the four prepared inactivated IBDV vaccines.

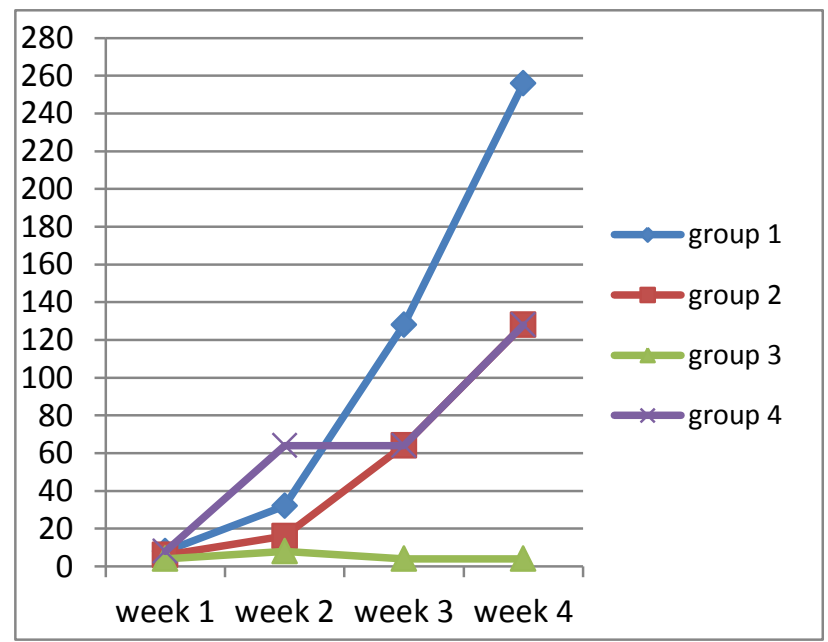

Group 1: vaccinated with inactivated IBD vaccine consisted of (variant isolate+virulent isolate+bursa vacc) Group2: vaccinated with inactivated IBD vaccine consisted of (variant isolate +bursa vacc)

Group 3: vaccinated with inactivated IBD vaccine (bursa vacc strain)

Group 4: vaccinated with inactivated IBD vaccine (variant isolate)

\section{Challenge test}

As shown in table (3), Protection percent in chicks vaccinated with the four prepared vaccines were $97.5 \%, 90 \%, 75 \%, 90 \%$ for group 1, 2, 3 and 4 respectively and $0 \%$ for challenged control unvaccinated (+ve) group. This result agreed with (Shaw and Davison, 2000) who mentioned that Protection against IBDV is highly dependent on the antigenic correlation between the vaccine and the circulating virus strains. Chicks in challenged control non vaccinated group showed atrophied yellowish bursa and slight hemorrhages on proventriculus This protection percent was confirmed by titration of the serum pre- challenge and one week post challenge using SNT and ELISA which indicated suitable IBD antibody titers and also confirmed by examination for clinical signs and development of lesions in challenged birds which showed no clinical signs or lesions in all vaccinated groups of birds showing protection.. These results agreed with (Silke $\boldsymbol{e t}$ al., 2003) who reported that virulent strain of IBDV induced the best protection against challenge virus replication in comparison with mild and intermediate strain of classical IBDV, also agreed with (Susan et al., 2013) who showed that the protection in challenged chicks which vaccinated with TCIBD (variant isolate) was in high percent (96-100\%) when they challenged by vvIBD virus and variant strain. Finally, the results of challenge test agreed with (OIE, 2016) who mentioned that The vaccine fails the challenge test unless at least $90 \%$ of the vaccinated chicken survives without showing either clinical signs or severe lesions in the bursae of Fabricius at the end of the observation period.

Figure 2: Mean IBD ELISA serum antibody titers in vaccinated chicks with the four prepared inactivated IBDV vaccines.

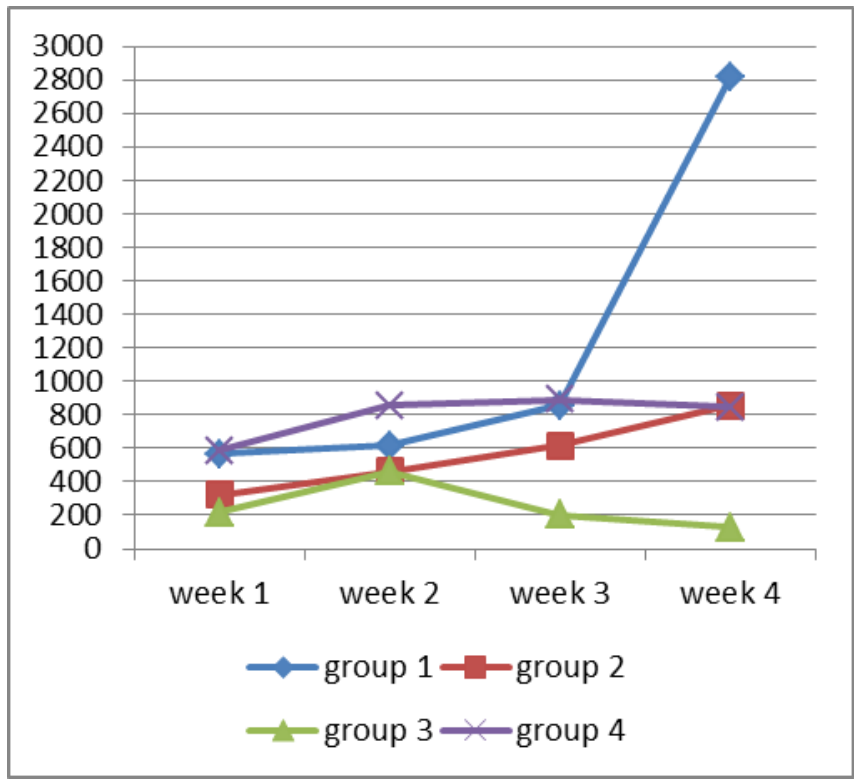

Group 1: vaccinated with inactivated IBD vaccine consisted of variant isolate+virulent isolate+bursa vacc)

Group2: vaccinated with inactivated IBD vaccine consisted of (variant isolate +bursa vacc)

Group 3: vaccinated with inactivated IBD vaccine (bursa vacc strain)

Group 4: vaccinated with inactivated IBD vaccine (variant isolate)

As shown in figure (3), the chicks of group 3 vaccinated with bursa vacc strain vaccine showed the lowest parameters comparing with the other groups while the chicks of group 1 vaccinated with local isolates and classical strain show the highest parameters comparing with the other groups.

\section{CONCLUSION}

It was concluded that using inactivated vaccine prepared from local isolates and standard classical IBDV strain was safe, potent and immunogenic in young chicks and may had major advantage for control IBD disease in Egypt. 
Table 3: Protection percent of chicks vaccinated with the four prepared inactivated IBDV vaccines after challenge using virulent IBDV

\begin{tabular}{|c|c|c|c|c|}
\hline \multirow{2}{*}{ 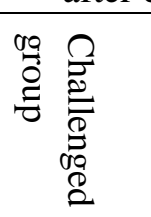 } & \multicolumn{3}{|c|}{ Number of chicks } & \multirow[b]{2}{*}{$\begin{array}{l}\text { Protection } \\
\text { percent } \%\end{array}$} \\
\hline & Challenged & Dead & Live & \\
\hline Group 1 & 40 & 1 & 39 & 97.5 \\
\hline Group 2 & 40 & 4 & 36 & 90 \\
\hline Group 3 & 40 & 10 & 30 & 75 \\
\hline Group 4 & 40 & 4 & 36 & 90 \\
\hline Group 5 & 40 & 40 & 0 & 0 \\
\hline Group 6 & 40 & 0 & 40 & 100 \\
\hline
\end{tabular}

Group 1: vaccinated with inactivated IBD vaccine consisted of (variant isolate+virulent isolate+bursa vacc) Group2: vaccinated with inactivated IBD vaccine consisted of (variant isolate +bursa vacc)

Group 3: vaccinated with inactivated IBD vaccine (bursa vacc strain)

Group 4: vaccinated with inactivated IBD vaccine (variant isolate)

**group (5): unvaccinated challenged (+ve) control group **group (6): unvaccinated unchallenged (-ve) control group

Figure 3: comparing the results of SNT, ELISA and protection $\%$ of the four prepared inactivated IBDV vaccines at the $4^{\text {th }}$ week post vaccination

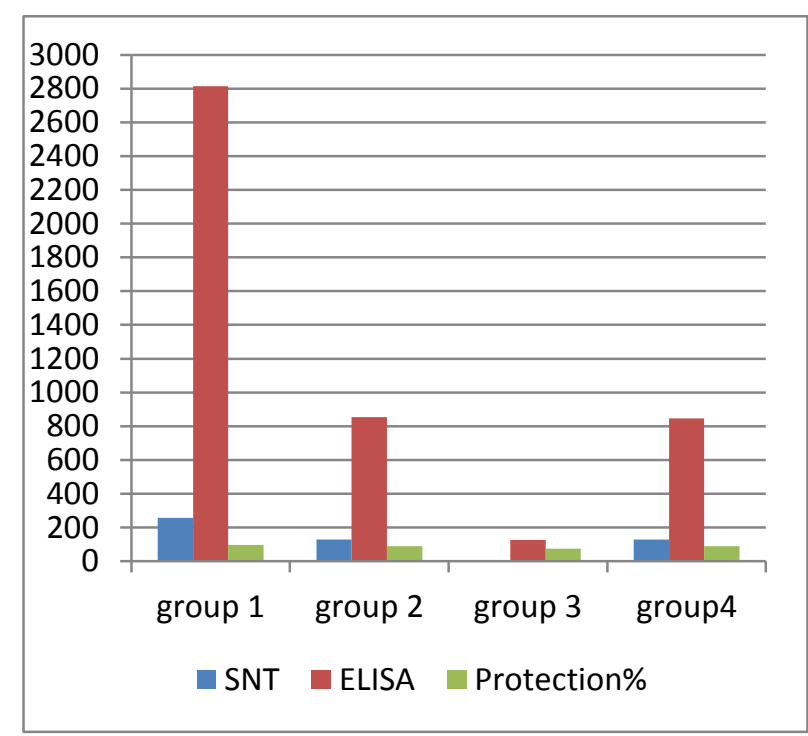

Group 1: vaccinated with inactivated IBD vaccine consisted of (variant isolate+virulent isolate+bursa vacc)

Group2: vaccinated with inactivated IBD vaccine consisted of (variant isolate +bursa vacc)

Group 3: vaccinated with inactivated IBD vaccine (bursa vacc strain)

Group 4: vaccinated with inactivated IBD vaccine (variant isolate)

\section{REFERENCES}

ABDEL-ALIM, G.A., AWAD, M.H.H., SAIF, Y.M. 2003. Characterization of Egyptian field strains of infectious bursal disease virus. Avian Dis. 47, 14521457.

ALLAN, W. H., LANCASTER, J. E., TÖTH, B. 1973. The production and use of Newcastle disease vaccines. Food and Agriculture Organization of the United Nations: Rome. P.53.

AMAL I.M. ABD EL-HADI 2001. Preparation and evaluation of killed $11511 \mathrm{~V}$ vaccine using new oil adjuvant. PhD Thesis, Virology, Cairo University, Giza, Egypt.

BEARD, C.W. 1989. Serological procedures in a laboratory manual for the isolation and identification of avian pathogens. 3rd Ed. Published by the American Association of Avian Pathologists.

BRIGGS, D. J., C. E. WHITFILL, J. K. SKEELES, J. D. STORY, AND K. D. REED 1986 Application of the positive/negative ratio method of analysis to quantitate antibody responses to infectious bursal disease virus using a commercially available eLISA. Avian Dis. 30:216-218

CFR (CODE OF AMERICAN FEDERAL REGULATION-13CFR) USA 2017. Published by office of the federal register nationalarchives records service, Animals and animal products Ch.111.30-11333.

CHANSIRIPORNCHAI, N. AND SASIPREEYAJAN, J. 2009. Comparison of the efficacy of the immune complex and conventionally live vaccine in broilers against infectious bursal disease infection. Thai J. Vet. Med. 39(2): 115-120.

CHO, Y. AND EDGAR, S. A. 1969. Characterization of the Infectious Bursal Agent. Poult. Sci. 48: 21022109.

COSGROVE, A.S. 1962. An apparently new disease of chicken. Avian disease 6: 385-389

COULIBALY F, CHEVALIER C, GUTSCHE I, POUS J, NAVAZA J, ET AL. 2005. The birnavirus crystal structure reveals structural relationships among icosahedral viruses. Cell 120: 761-772.

EL-BATRAWI, A. M. 1990. "Studies on severe outbreaks of infectious bursal disease. 1-The natural and experimental disease" in Proceedings of the 2nd Scientific Conference of the Egyptian Veterinary Poultry Association, pp. 339-252.

ETERRADOSSI N. and SAIF Y.M. 2013. Chapter 7: Infectious bursal disease. In: Diseases of Poultry, 13th Edition, Editor in chief D.E. Swayne, John Wiley \& Sons Inc., Ames, Iowa, USA, pp 219-246.

ETERRADOSSI N., ARNAULD C., TEKAIA F., TOQUIN D., LE COQ H., RIVALLAN G., GUITTET M., DOMENECH J., VAN DEN BERG T.P. \& SKINNER M.A. 1999. Antigenic and genetic relationships between European very virulent infectious bursal disease viruses and an early West African isolate. Avian Pathol., 28, 36-46.

FLORENCE, G., BURLESON, T., CHAMBERS, M., DANNY, L.W. 1992. Virology: A Laboratory Manual. New York: Academic Press. 
HABIB, M., IFTIKHAR, H., HAMID, I., ZONG, Y., JIANG, S. AND NING, N. 2006. Immunogenicity of formaldehyde and binary ethylenimine inactivated infectious bursal disease virus in broiler chicks. Journal of Zhejiang University Science. 7(8):660664.

HELAL, A.M., SUSAN, S. EL-MAHDY, MANAL, A. AFIFY 2012. Study the Prevalence of Variant IBD Strains in Some Egyptian Chicken Farms. New York Science Journal; 5 (6):8-11.

HUSSEIN, A.H., ALY, A.N., SULTAN, H., AL-SAFTY, M. 2003. Transmissible viral pronventriculitis and stunting syndrome in broiler chicken in Egypt. 1. Isolation and characterized of variant infectious bursal disease virus. Vet Med J Giza; 51(3):445-62.

KHATRI M, SHARMA JM. 2007. Modulation of macrophages by infectious bursal disease virus. Cytogenet Genome Res. 2007; 117(1-4):388-393.

LUKERT, P.D., AND SAIF, Y.M. 1997. Infectious bursal disease. In: Calnek BW, Barnes HJ, Beard CW, Mcdougald LR, Saif YM (11 eds) Diseases of poultry. Iowa State University Press, Iowa, pp 721738.

LUKERT, P.D., AND SAIF, Y.M. 2003. Infectious bursal disease. In: Saif YM, Barnes HJ, Glisson JR, Fadly AM, McDougald LR, Swayne DE, editors. Diseases of Poultry, Ames, IA: Iowa State University Press, p. 161-179.

MAAS, R.A., VENEMA, S., OEI, H.L., POL, M.A., CLAASSEN, J.T.M. AND HUURNE, A.H.M. 2001. Effecacy of inactivated infectious bursal disease (IBD) vaccine: coparison of serology with protection of progeny chickens against IBD virus strain of varying virulence. Avian pathology, (30): 345-354.

MAGDA M.A.MOUSTAFA, EL SHORBAGY M.A. AND SUSAN Y. YOUNIS 2013. Evaluation of Different Vaccination Programs For Nd, Ai And Ibd Viruses In Broiler Chickens. Benha Veterinary Medical Journal, VOL. 24, NO. 2, JUNE 2013: 70-81

MAHGOUB, H.A. 2010. An over view of infectious bursal disease. Arch. Virol. 157: 2047-2057.

MC FERRAN, J. B.; MCNULTY, M. S.; KILLOP, E. R.; CONNOR, T. J.; MCCRACKEN, R. M.; COLLINS, P.S. AND ALLAN, G. M. 1980. Isolation and serological studies with Infectious Bursal Disease Virus from fowl, turkeys and ducks: Demonstration of a second serotype. Avian Pathol. 9: 395-404.

METWALLY, A.M., SABRY, M.Z., SAMI, A.M., OMER, M.N., YOUSIF, A.A., REDA, M. 2003. Direct detection of variant infectious bursal disease virus in vaccinated Egyptian broiler flocks using antigen - capture Elisa. Vet Med J Giza; 51(1):10519.

METWALLY, A.M., YOUSIF, A.A., SHAHEED, I.B., MOHAMMED, W.A., SAMY, A.M., REDA, I.M. 2009. Re-emergence of very virulent IBDV in Egypt. Int J Virol; 5:1-17.

MICHAEL, A., GUTER, B., BARBAKOV, M., GALILI, G., PITKOVKI, J., MAARRY, T., YAHUDA, H. 1997. Development of infectious bursal disease (IBD) vaccine of intermediate invasevness from a very virulent (vv) IBD virus. Proc.XIth lnt.Cong.Wld.Vet.Assoc. Budapest. Hungary. Pp 185.

MOHAMED, M.A., ELZANATY, K.E.S., BAKHIT, B.M., AND SAFWAT, M.M. 2014. Genetic Characterization of Infectious Bursal Disease Viruses Associated with Gumboro Outbreaks in Commercial Broilers from Asyut Province, Egypt. ISRN Veterinary Science, Volume 2014, Article ID 916412, 9

pages. http://dx.doi.org/10.1155/2014/916412

MULLER, H., ISLAM, M.R., RAUE, R. 2003. Research on infectious bursal disease-the past, the present and the future. Vet Microbiol; 97:153-65.

NADA A. FATHI 2015. Identification and studies on characterization of recent isolate of IBD virus and trials to prepare inactivated vaccine. Ph. D.v. Sc .virology. Benha University

NADIA M. IBRAHIM 2011. Immunological studies on the local Infectious Bursal Disease (IBD) Virus adapted on specific pathogen free embryonated chicken eggs (SPF-ECE). Egypt. J. Agric. Res., 89 (2), pp. 709-729.

OIE TERRESTRIAL MANUAL 2016. Infectious bursal disease (Gumboro disease). Chapter 2. 3. 12.

RAO, S.U.M., SAMBAMURTI, B., MALLICK, B.B. 1978. Dwarfing and mortality of chicken embryos caused by indigenous isolates of infectious bursal disease virus. Indian J. Anim. HIth, 17:111-114.

RAUTENSCHLEIN, S., H. Y. YEH, AND J. M. SHARMA 2002. The role of $\mathrm{T}$ cells in protection by an inactivated infectious bursal disease virus vaccine. Vet. Immunol. Immunopathol. 89:159167.

REED, L.J., AND MUENCH, H. 1938. A simple method of estimating fifty percent end points. Amr. J. Hyg., 27: 493.

RINALDI, A., CESSI, D., CERVICO, G., LODETTI, E. 1972. Attenuation of Gumboro disease virus and vaccination trials under field conditions. Nuova Vet., 48 (4): 216-223.

SARA ABDEL MAWGOD, ABDEL SATAR ARAFA, HUSSEIN A. HUSSEIN 2014. Molecular genotyping of the infectious bursal disease virus (IBDV) isolated from broiler flocks in Egypt. International Journal of Veterinary Science and Medicine, 2, 46-52.

SAPATS S. I., AND IGNJATOVIC J. 2000. Antigenic and sequence heterogeneity of infectious bursal disease virus strains isolated in Australia. Arch Virol. 145: 773-785. doi: 10.1007/s007050050670

SCHIJNS, V.E.J.C, SHARMA, J., AND TARPEY, I. 2008. Practical aspects of poultry vaccination. In: Davison F, Kaspers B, Schat KA (eds) Avian immunology. Academic Press and Elsevier Ltd, Amsterdam; London, pp 373-393

SHAW I, AND DAVISON TF. 2000. Protection from IBDV-induced bursal damage by a recombinant fowlpox vaccine, fpIBD1, is dependent on the titre of challenge virus and chicken genotype. Vaccine 18: 3230-3241.

SNYDER, D.B., MARGUARDT, W.W., MALLINION, E.T., RUSSETCOHEN, E., 
SVAGE, P.K. AND ALLEN, D.C. 1986. Rapid serological profiling by enzyme linked immunosorbent assay. Avian Dis., 30:139-148.

SNYDER, D.B., LANA, D.P., SAVAGE, P.K., YANCEY, F.S., MENGEL, S.A., MARQUARDT, W.W. 1988. Differentiation of infectious bursal disease viruses directly from infected tissues with neutralizing monoclonal antibodies: evidence of a major antigenic shift in recent field isolates. Avian Dis. 32:535-539.

SILKE RAUTENSCHLEIN, H-Y. YEH, AND J. M. SHARMA 2003. Comparative Immunopathogenesis of Mild, Intermediate, and Virulent Strains of Classic Infectious Bursal Disease Virus. Avian Diseases. Vol. 47, Issue 1, pg(s) 66- 78.

SUSAN S. EL-MAHDY, MANAL, A. AFIFY AND A. M. HELAL 2013. Evaluation of live gumboro vaccine prepared from local variant strain for control of infectious bursal disease in Egypt. Veterinary World. Vol. 6. EISSN: 2231-0916.

SUSAN S. EL-MAHDY, HAYAM, FAROUK, ABD EL-WANIS, N.A AND HAMOUD, M.M. 2013. Comparative studies between different commercial types of live Infectious bursal disease [IBD] vaccine strains in Egyp. American Journal of Research Communication. Vol 1(10)

THAYER S. G., C. S. EIDSON, AND S. H. KLEVEN 1983. Multivalent Inactivated Virus Oil Emulsion Vaccines in Broiler Breeder Chickens. III. Trivalent Newcastle Disease, Infectious Bursal Disease, and Arthritis/Tenosynovitis Viruses Vaccine in Primed Breeders. Poultry Disease Research Center, Department of Avian Medicine, College of Veterinary Medicine, University of Georgia, Athens, Georgia 30605

TSUKAMOTO, K., N. TANIMURA, S. KAKITA, K. OTA, M. MASE, K. IMAI, AND H. HIHARA 1995. Efficacy of three live vaccines against highly virulent infectious bursal disease virus in chickens with or without maternal antibodies. Avian Dis. 39:218-229.

VAN DEN BERG, T.P., MORALES, D., ETERRADOSSI, N., RIVALLAN, G., TOQUIN, D., RAUE, R., ZIERENBERG, K., ZHANG, M. F., ZHU, Y.P., WANG, C.Q., ZHENG, H.J., WANG, X., CHEN, G.C., LIM, B.L. AND MULLER, H. 2004. Assessment of genetic, antigenic and pathotypic criteria for the characterization of IBDV strains. Avian Pathology, 33(5), 470-476

VILLEGAS, P. 1990. Laboratory manual- avian virus disease. The university, College of Vet. Med., Athens, Georgia, USA.
How to cite this article:

Nada, A. Fathy and Abd El-Moneam M.

M. 2018. Preparation of Inactivated Infectious Bursal Disease Virus Vaccine from Classical Strain and Local Variant Isolates. Journal of Applied Veterinary Sciences, 3 (1): $34-42$.

DOI: https://dx.doi.org/10.21608/javs.2018.62720 